\title{
Pengembangan Modul Elektrokimia dengan Pendekatan Kontekstual Chemoentrepreneurship untuk SMA
}

\author{
Bayu Bramasta Giri ${ }^{1}$, Suhadi Ibnu ${ }^{1}$, Sutrisno ${ }^{1}$ \\ ${ }^{1}$ Pendidikan Kimia-Universitas Negeri Malang
}

\begin{tabular}{l} 
INFO ARTIKEL \\
\hline Riwayat Artikel: \\
Diterima: $12-02-2020$ \\
Disetujui: $27-08-2020$ \\
\hline
\end{tabular}

\section{Kata kunci:}

contextual approach; chemoentrepreneurship; electrochemical module; learning outcomes; pendekatan kontekstual; chemoentrepreneurship; modul elektrokimia; hasil belajar

\author{
Alamat Korespondensi: \\ Bayu Bramasta Giri \\ Pendidikan Kimia \\ Universitas Negeri Malang \\ Jalan Semarang 5 Malang \\ E-mail: baybramata@gmail.com
}

\begin{abstract}
ABSTRAK
Abstract: The purpose of this research is to produce an electrochemical contextual chemoentrepreneurship module that is validated according to the criteria of BSNP materials eligibility, namely content eligibility, linguistic feasibility, presentation feasibility, and the feasibility of the graft and knowing Effectiveness of student learning outcomes. The development model adopted the Model 4-D with the stages of defining, designing, developing, and desimination. Data on the feasibility of teaching materials is obtained from content and material validation, individual test, field test is limited while the effectiveness data is obtained from the difference learning outcomes between the experimental and the control group. The validation and test results are obtained as follows (1) the average value of the content expert validator and learning material is very decent criteria, (2) individual trials with excellent criteria, and (3) limited field trials is Very good criteria. The development module is well-deserved to be used as a learning resource and effectively improve student learning outcomes.
\end{abstract}

\begin{abstract}
Abstrak: Penelitian ini bertujuan menghasilkan modul elektrokimia kontekstual Chemoentrepreneurship tervalidasi sesuai kriteria kelayakan bahan ajar BSNP, yakni isi, kebahasaan, penyajian, dan kegrafisan serta mengukur efektivitas modul terhadap hasil belajar. Model pengembangan mengikuti model 4-D dengan tahapan pendefinisian, perancangan, pengembangan, dan desiminasi. Data kelayakan modul diperoleh dari validasi isi dan materi, uji perorangan, uji lapangan terbatas sedangkan data efektivitas diperoleh dari perbedaan hasil belajar antara kelompok eksperimen dengan kelompok kontrol. Hasil penelitian (1) nilai validasi isi dan materi pembelajaran memiliki kriteria sangat layak, (2) uji coba perorangan kriteria sangat baik, dan (3) uji coba lapangan kriteria sangat baik. Modul efektif digunakan dalam pembelajaran hal ini ditunjukkan oleh ketuntasan hasil belajar peserta didik kelompok eksperimen lebih tinggi daripada kelompok kontrol.
\end{abstract}

Kimia merupakan ilmu yang pada awalnya diperoleh dan dikembangkan berdasarkan percobaan (Özgelen, 2012), namun pada perkembangan selanjutnya kimia juga diperoleh dan dikembangkan berdasarkan teori. Peserta didik dalam mempelajari ilmu kimia memerlukan bekal yang cukup tinggi dan beragam yaitu kemampuan berpikir formal, kemampuan menjelaskan secara mikroskopis, makroskopis, dan simbolik (Fatmawati, 2013). Melatih kemampuan berpikir perlu diberdayakan, direncanakan dengan sengaja melalui model, pendekatan, metode, dan strategi pembelajaran yang sesuai dengan kondisi saat kegiatan pembelajaran dengan harapan peserta didik akan mampu mengasimilasi, mengakomodasi, dan menemukan konsep melalui hubungan antar informasi yang terstruktur, dan sesuai dengan kondisi kehidupan nyata (Chattopadhyay, 2005;Corebima, 2011; (Nurhadi \& Senduk, 2003). Penting bagi guru kimia untuk mengintegrasikan prinsip dasar kimia dengan dunia nyata karena peserta didik akan lebih terbuka dalam berpikir saat kegiatan pembelajaran (Cracolice \& Ward, 1998). Peserta didik akan memiliki sikap yang positif terhadap pembelajaran kimia jika mereka terlibat langsung dalam suatu eksperimen dalam laboratorium dengan metode pembelajaran yang menarik dan bervariasi (Yunus \& Ali, 2012; Ali, 2012).

Pendekatan yang dapat membantu peserta didik dalam menemukan makna dan menghubungkan materi dengan dunia nyata adalah pendekatan kontekstual (Johnson, 2002). Pendekatan kontekstual mengenalkan suatu konsep berdasarkan konteks yang telah diketahui peserta didik sebelumnya dengan mengambil masalah dari kehidupan sehari-hari. Kurikulum kimia yang menerapkan konteks dalam kaitan dengan sains, teknologi, dan masyarakat akan membangun pemahaman sains secara komprehensif (Bennett \& Holman, 2006; King et al., 2007). Pendekatan kontekstual memiliki tujuh komponen utama yang saling terintegrasi, yakni konstruktivisme, pertanyaan bermakna, inkuiri (penemuan), masyarakat belajar, pemodelan, penilaian autentik dan refleksi (Nurhadi \& Senduk, 2003). Berbagai penelitian menunjukkan bahwa kegiatan pembelajaran dengan 
pendekatan kontekstual yang terencana dengan baik akan sangat efektif meningkatkan keaktifan, pemahaman, hasil belajar dan peserta didik akan lebih menikmati pembelajaran sains karena kemampuan berpikir ilmiah yang dimiliki bermanfaat (Nentwig et al., 2007; Bennett \& Holman, 2006).

Pembelajaran dengan pendekatan kontekstual yang saat ini dikembangkan di Jerman adalah Chemie im Kontext. Pendekatan ini dilatarbelakangi rendahnya proses mengaitkan antara pemahaman konsep dengan fenomena kehidupan nyata dalam kegiatan pembelajaran. Pendekatan ini dapat meningkatkan kualitas proses kegiatan pembelajaran kimia karena pemahaman konsep dasar dibangun dari sebuah konteks dimana peserta didik menemukan pemahamannya secara mandiri dari berbagai sumber (Nentwig et al., 2007). Konstruksi penemuan konsep Chemie im Kontext ditunjukkan gambar 1. Pengembangan konstruksi penemuan konsep di atas dirinci melalui siklus belajar Chemie im Kontext yang ditunjukkan gambar 2.

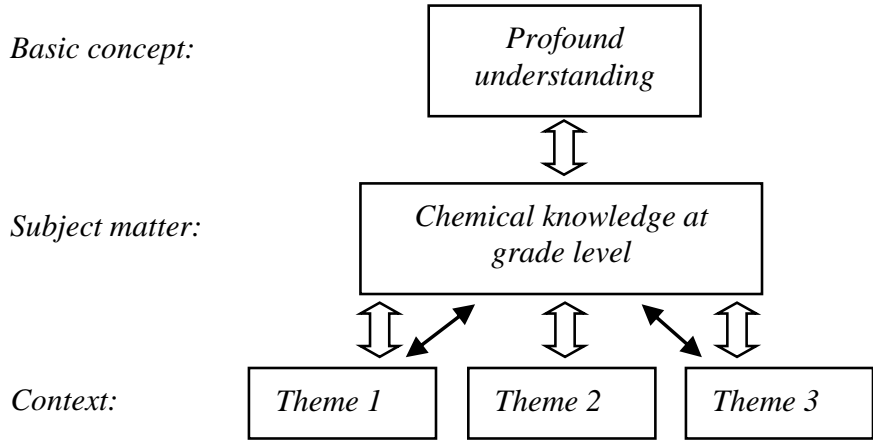

Gambar 1. Sistematika Penemuan Konsep Dasar

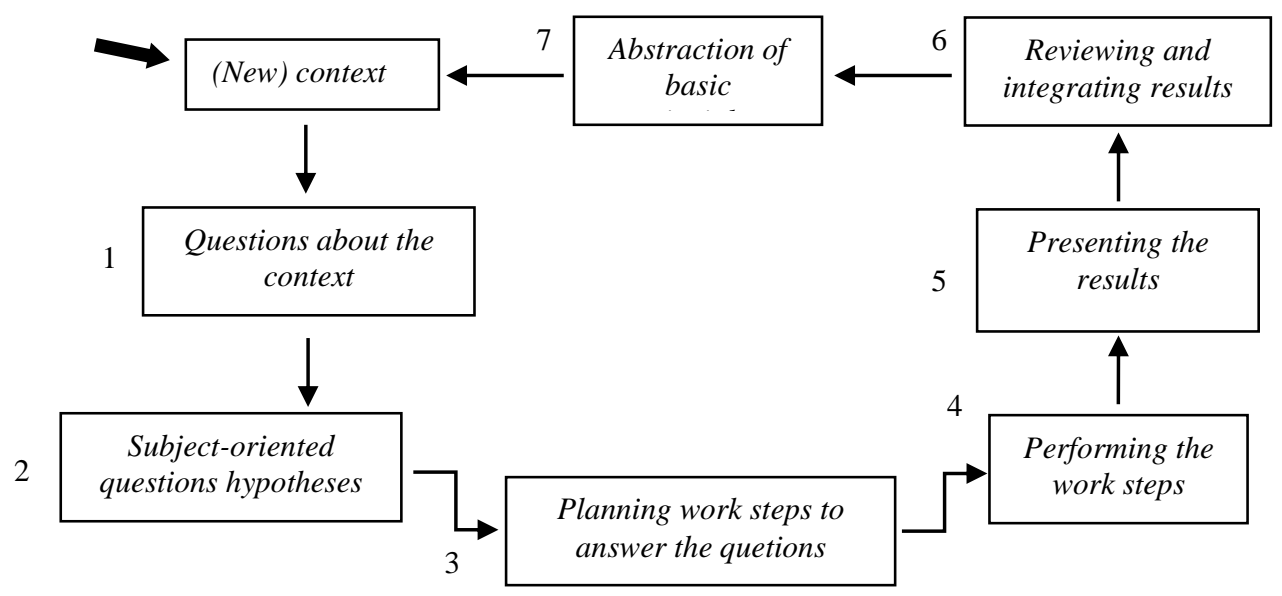

Gambar 2. Siklus Proses Belajar Chemie im Context

Dalam Chemie im Kontext s1kıus proses perajar aı atas aııntegrasıkan ke aaıam empat rase pembelajaran kontekstual yakni fase kontak (contact phase), fase ingin tahu (curiosity phase), fase elaborasi (elaboration phase), fase integrasi (nexus and integrating phase). Uraian empat fase di atas, yakni (1) fase kontak dimulai dengan menyajikan suatu konteks materi elektrokimia dalam kehidupan sehari-hari kemudian peserta didik mengekspresikan pengetahuan awalnya dan mengembangkan ide tentang topik pembelajaran lalu mempresentasikannya, (2) fase ingin tahu peserta didik mengajukan pertanyaan tentang konteks dan mengembangkan strategi menemukan jawaban pertanyaan untuk mengeksplorasi lebih dalam suatu topik yang akan di pelajari, (3) fase elaborasi peserta didik melakukan eksplorasi pengetahuan melalui kegiatan belajar individu maupun kelompok yang terstruktur sampai diperoleh pengetahuan konsep yang benar, dan (4) tahap integrasi peserta didik mengintegrasi pengetahuan konsep yang ditemukan dengan konteks lain.

Peserta didik sebagai objek dalam suatu kegiatan pembelajaran harus dibekali dengan berbagai wawasan dan keterampilan. Berbagai ilmu yang diterima saat proses pembelajaran diharapkan dapat saling terintegrasi sehingga bermanfaat dalam kehidupannya setelah lulus dari sekolah. Salah satu bentuk inovasi pembelajaran dengan pendekatan kontekstual adalah chemoentrepreunership. Proses pembelajaran ini mengaitkan ilmu kimia dengan konsep kewirausahaan (Kusuma, 2011). Materi yang dipelajari peserta didik diterapkan untuk mengolah suatu bahan menjadi produk yang bernilai ekonomi. Inti dari 
Chemoentrepreneurship bukan membentuk peserta didik menjadi wirausahawan, namun lebih pada penumbuhan minat dan inspirasi berwirausaha melalui proses pembelajaran (Josia Sanchaya Hendrawan, 2017). Penelitian berkaitan dengan pembelajaran menggunakan pendekatan Chemoentrepreunership sudah terbukti efektif dalam meningkatkan kemampuan kognitif, minat berwirausaha dan life skill (Kusuma, 2011; Sa'adah \& Supartono, 2013 ; Sumarti et al., 2018).

Salah satu pendukung dalam pembelajaran kontekstual adalah penyediaan bahan ajar yang relevan. Pendidik dituntut lebih kreatif dalam kegiatan pembelajaran agar dapat membantu peserta didik mempelajari kimia di kelas maupun secara mandiri (Lawhon, 1976). Bahan ajar yang dikembangkan sendiri oleh guru memiliki keunggulan diantaranya bisa menyesuaikan dengan kondisi dan karakteristik lapangan dimana pendidik tersebut mengajar (Hernawan et al., 2008). Pengembangan bahan ajar dapat mempertimbangkan kondisi peserta didik dalam hal tahapan perkembangan psikologis, pengetahuan awal yang dimiliki, keadaan lingkungan sosial, budaya, dan letak geografis (Mursalin, 2015; Prastowo, 2014).

Penggunaan bahan ajar juga sebaiknya diupayakan dapat memecahkan permasalahan di lapangan. Masalah di lapangan yang dimaksud adalah alokasi waktu dan bahan ajar. Hal ini sesuai dengan permasalahan pembelajaran yang terjadi di SMA Negeri 5 Madiun dimana waktu pembelajaran pada kelas XII semester V yang mempunyai materi pembelajaran sangat padat dikarenakan kebijakan sekolah untuk memampatkan dan memasukkan materi semester VI ke semester V sehingga pada semester VI dapat fokus pada ujian nasional. Hasil analisis data penilaian harian materi elektrokimia peserta didik SMA Negeri 5 Madiun pada tahun pelajaran tahun 2015/2016 dan 2016/2017 secara berturut yaitu 75,56 dan 76,2 pada materi elektrokimia adalah 74,0 dengan KKM 75,0 artinya masih di bawah KKM. Pada tahun pelajaran berikutnya yakni 2015/2016 dan 2016/2017 telah mencapai KKM 75,0 dengan nilai rata-rata secara berturut-turut 75,6 dan 76,2 namun hal ini masih dirasa belum optimal.

Terkait Penggunaan bahan ajar sebagian besar peserta didik hanya menggunakan LKS sebagai sumber belajar, namun setelah dianalisis LKS tersebut berisi informasi singkat (informatif) dan soal-soal latihan. Informasi yang disajikan sangat terbatas dari segi kedalaman, keluasan dan tidak mengarahkan peserta didik untuk mengonstruksi pengetahuan yang dipelajarinya. Maka perlu dikembangkan bahan ajar yang cocok dalam menyelesaikan permasalahan tersebut. Salah satu jenis bahan ajar yang dapat digunakan dalam menyelesaikan permasalahan di atas adalah modul. Modul dapat membantu peserta didik dalam berbagai kondisi belajar. Modul yang tersusun secara terstruktur dan terencana dengan baik dapat digunakan secara mandiri oleh peserta didik (Depdiknas, 2008). Penggunaan modul dapat mendukung terciptanya kegiatan pembelajaran yang berkualitas karena dengan menggunakan modul kegiatan pembelajaran akan tuntas dan menghasilkan output yang jelas (Depdiknas, 2008).

Modul memiliki struktur yang lengkap yakni terdapat tujuan pembelajaran, KI-KD, indikator pencapaian kompetensi, cara penggunaan modul, materi yang disajikan disertai dengan ilustrasi dan contoh gambar, rangkuman, soal uji kompetensi, tugas terstruktur, instrumen penilaian, umpan balik, dan referensi rujukan (Andriani, 2011). Desain modul dapat dikelola menjadi sumber belajar yang berbeda dengan dari buku pelajaran biasa. Agar peserta didik tertarik mempelajari modul maka Variasi berupa strategi pembelajaran, cara belajar, penyampaian bahasa yang komunikatif, kegiatan belajar yang interaktif, dan penggunaan ilustrasi grafis yang menarik dapat digunakan. Beberapa penelitian tentang pembelajaran menggunakan modul telah terbukti efektif meningkatkan pemahaman, kepercayaan diri, hasil belajar, kerja sama dan aktivitas peserta didik di dalam kelas selama kegiatan pembelajaran (Jacques-Fricke et al., 2009; Prayitno, Nanik, \& Sri, 2017; Wikhdah, 2016).

\section{METODE}

Penelitian ini merupakan penelitian pengembangan (research and development) dengan orientasi menghasilkan atau mengembangkan sebuah produk. Produk yang dimaksud adalah modul elektrokimia dengan pendekatan kontekstual Chemoenterpreneurship untuk SMA.

Model pengembangan di dalam penelitian ini mengadaptasi model Thiagarajan et al., (1974) yakni model 4-D (Four$D$ model). Model ini sangat sistematis dan langkah-langkah pengembangannya mudah diikuti serta sesuai dengan panduan penulisan modul yang disarankan Depdiknas (2008). Empat tahap pengembangan model yaitu tahap pendefinisian (Define), perancangan (Design), pengembangan (Develop), dan penyebarluasan hasil pengembangan (Disseminate). Pengembangan modul elektrokimia tahap keempat yaitu tahap penyebarluasan hasil pengembangan (Disseminate) hanya dilakukan terbatas kepada guru dan peserta didik kelompok eksperimen XII MIPA 1 SMA Negeri 5 Madiun untuk dipakai dalam kegiatan pembelajaran dan tidak disebarkan ke sekolah lain.

Instrumen yang dipakai untuk mengumpulkan data berupa dokumentasi, angket, dan tes hasil belajar. Data dokumentasi yakni data dari kurikulum berupa KI-KD mata pelajaran kimia, hasil belajar peserta didik sebelumnya, dan analisis sumber belajar yang digunakan di lapangan. Angket yang digunakan terdiri dari dua macam angket yaitu angket validasi isi modul dan angket respon peserta didik. Tiap angket memiliki dua bagian yaitu penilaian kelayakan serta komentar dan saran. Data hasil belajar peserta didik diperoleh dengan instrumen tes hasil belajar berupa soal post test pada setiap akhir kegiatan pembelajaran.

Data yang diperoleh berupa data kuantitatif dan kualitatif. Data kuantitatif diperoleh dari angket yang telah di isi oleh validator ahli isi dan materi pembelajaran, subjek uji coba perorangan dan lapangan terbatas serta data nilai hasil post test. Data kualitatif diperoleh dari komentar dan saran perbaikan dari ahli isi dan materi pembelajaran, subjek uji coba perorangan dan lapangan terbatas. Data berupa komentar dan saran dari ahli isi dan materi pembelajaran, subjek uji coba perorangan serta subjek uji coba lapangan terbatas diolah dan dianalisis dengan teknik deskriptif kualitatif. Hasil pengolahan ini digunakan 
sebagai bahan revisi modul pengembangan. Data hasil angket validasi ahli isi dan uji coba perorangan serta uji lapangan terbatas diolah dengan teknik analisis statistik deskriptif persentase.

Efektivitas modul dalam uji coba lapangan terbatas diketahui dengan menggunakan rancangan eksperimen semu (quasi experiment)yaitu dengan membandingkan nilai postest peserta didik yang menggunakan modul hasil pengembangan (kelompok eksperimen) kelas XII MIPA 1 dengan peserta didik yang menggunakan bahan ajar konvensional (kelompok kontrol) kelas XII MIPA 2. Data nilai postes diuji dengan independent sample t-test. Selain dengan uji-t, untuk mengetahui keefektifan modul pengembangan dapat diketahui dengan mengukur pencapaian kompetensi peserta didik. Pencapaian kompetensi peserta didik ditentukan dengan nilai kriteria ketuntasan minimal (KKM). Untuk mata pelajaran kimia kelas XII MIPA SMAN 5 Madiun, nilai KKM yang ditetapkan yaitu 75,0. Apabila 80\% peserta didik dapat mencapai nilai KKM maka modul hasil pengembangan dapat diartikan efektif dan layak untuk digunakan dalam kegiatan pembelajaran.

\section{HASIL}

Format modul hasil pengembangan menggunakan acuan yang diperoleh dari hasil kajian format modul yang diterbitkan oleh Depdikbud dan disesuaikan dengan pendekatan yang digunakan. Format modul hasil pengembangan yaitu (1) pendahuluan berisi sampul, kata pengantar, daftar isi, daftar tabel, dan daftar gambar, deskripsi modul, pendekatan pembelajaran modul, petunjuk penggunaan modul bagi peserta didik, materi prasyarat, kompetensi inti, kompetensi dasar,indikator pembelajaran, dan rencana belajar, (2) kegiatan pembelajaran terdiri dari tiga kegiatan pembelajaran yakni kegiatan pembelajaran 1 sel Volta, kegiatan pembelajaran 2 korosi, dan kegiatan pembelajaran tiga sel elektrolisis dimana dalam setiap kegiatan berisi tujuan pembelajaran, uraian materi, rangkuman, uji kompetensi, latihan (cek pemahaman) dan umpan balik, (3) penutup berisi glosarium, kunci jawaban, dan daftar pustaka. Pola pengadopsian pendekatan kontekstual chemie im kontext dalam setiap kegiatan pembelajaran ditunjukkan gambar 3. Hasil validasi ahli isi dan materi pembelajaran terhadap modul hasil pengembangan disajikan pada tabel 1 . Hasil penilaian uji coba perorangan terhadap modul hasil pengembangan disajikan pada tabel 2. Hasil penilaian uji coba lapangan terbatas terhadap modul hasil pengembangan disajikan pada tabel 3. Hasil penilaian validasi soal post test oleh dosen terhadap modul hasil pengembangan disajikan pada tabel 4 . Hasil pengelompokan perolehan nilai post test kelompok eksperimen disajikan pada tabel 5. Hasil pengelompokan perolehan nilai post test kelompok kontrol disajikan pada tabel 6. Hasil analisis Independent Samples $t$-Test terhadap nilai post test kelompok eksperimen dan kelompok kontrol disajikan pada tabel 7.

\begin{tabular}{|c|c|c|c|c|c|}
\hline Fase Kontak & Fase Ingin Tahu & $\Rightarrow$ & Fase Elaborasi & $\Rightarrow$ & Fase Integrasi \\
\hline $\begin{array}{l}\text { - Peserta didik diberikan } \\
\text { fakta-fakta dalam } \\
\text { kehidupan sehari-hari }\end{array}$ & $\begin{array}{l}\text { - Peserta didik di berikan } \\
\text { Pertanyaan-pertanyaan } \\
\text { untuk dijawab sesuai } \\
\text { dengan pengetahuan } \\
\text { awal yang dimilikinya } \\
\text { - Pertanyaan dijawab } \\
\text { oleh peserta didik } \\
\text { sebagai jawaban } \\
\text { sementara }\end{array}$ & & $\begin{array}{l}\text { - Peserta didik menggali } \\
\text { informasi untuk } \\
\text { menemukan konsep- } \\
\text { konsep materi yang } \\
\text { dipelajari dan } \\
\text { menemukan jawaban } \\
\text { atas pertanyaan- } \\
\text { pertanyaan yang } \\
\text { disajikan pada tahap } \\
\text { sebelumnya. } \\
\text { - Peserta didik } \\
\text { mempelajari uraian } \\
\text { materi yang disajikan } \\
\text { pada modul. }\end{array}$ & & $\begin{array}{l}\text { - Peserta didik } \\
\text { mengintegrasikan } \\
\text { pengetahuannya dengan } \\
\text { konteks lain } \\
\text { - Peserta didik } \\
\text { mengerjakan tugas } \\
\text { berupa pengkajian } \\
\text { artikel dan mengerjakan } \\
\text { uji kompetensi. } \\
\text { - Peserta didik membaca } \\
\text { dan memahami sajian } \\
\text { chemoentreprene- } \\
\text { urship. }\end{array}$ \\
\hline
\end{tabular}

Gambar 3. Pola Pengadopsian Pendekatan Kontekstual Chemie Im Kontext Dalam Setiap Kegiatan Pembelajaran

Tabel 1. Hasil Penilaian Modul oleh Validator Ahli Isi dan Materi Pembelajaran

\begin{tabular}{|c|c|c|c|c|c|}
\hline \multirow[b]{2}{*}{ No } & \multirow[b]{2}{*}{ Hasil Penilaian } & \multicolumn{2}{|c|}{ Validator } & \multirow[b]{2}{*}{ Rata-rata Hasil Penilaian } & \multirow[b]{2}{*}{ Kriteria } \\
\hline & & Dosen Kimia FMIPA UM & $\begin{array}{c}\text { Guru Kimia SMAN } 5 \text { dan } \\
\text { SMK } 3 \text { Madiun }\end{array}$ & & \\
\hline 1 & Kelayakan isi & $93.8 \%$ & $93.8 \%$ & $93,8 \%$ & Sangat Layak \\
\hline 2 & Kebahasaan & $97.5 \%$ & $95.0 \%$ & $96,3 \%$ & Sangat Layak \\
\hline 3 & Sajian & $93.5 \%$ & $92.9 \%$ & $93,2 \%$ & Sangat Layak \\
\hline 4 & Kegrafisan & $85.0 \%$ & $82.5 \%$ & $83,8 \%$ & Sangat Layak \\
\hline
\end{tabular}


Tabel 2. Hasil Penilaian Modul oleh Subjek Uji Coba Perorangan

\begin{tabular}{clcc}
\hline No & \multicolumn{1}{c}{ Aspek yang Dinilai } & Rata-rata Skor & Kriteria \\
\hline 1 & Modul dapat menambah wawasan dan pengetahuan & 95,8 & Sangat baik \\
2 & Bahasa mudah dipahami, komunikatif dan interaktif & 93,8 & Sangat baik \\
3 & Langkah pembelajaran mudah diikuti sehingga dapat meningkatkan & 95,8 & Sangat baik \\
& minat, rasa ingin tahu, motivasi belajar & & \\
4 & Gambar dan Lay out (tata letak), dan font (jenis dan ukuran) menarik & 93.1 & Sangat baik \\
5 & Muatan Chemoentrepreneurship (kewirausahaan) sesuai dengan materi & 95.8 & Sangat baik \\
& dan dapat meningkatkan life skill & & \\
\hline & $\quad$ Rata-rata penilaian uji perorangan (keterbacaan) & 94,9 & Sangat baik \\
\hline
\end{tabular}

Tabel 3. Hasil Penilaian Modul oleh Subjek Uji Coba Lapangan Terbatas

\begin{tabular}{clcc}
\hline No & Hasil Penilaian & Rata-Rata Hasil Penilaian & Kriteria \\
\hline 1 & Kelayakan isi & 87,1 & Sangat baik \\
2 & Kebahasaan & 80,1 & Sangat baik \\
3 & Sajian & 82,5 & Sangat baik \\
4 & Kegrafisan & 80,5 & Sangat baik \\
\hline & Rata-rata & 82,5 & Sangat baik \\
\hline
\end{tabular}

Tabel 4. Hasil Validasi Soal Post test oleh Dosen Kimia UM

\begin{tabular}{clcc}
\hline No & \multicolumn{1}{c}{ Hasil Penilaian } & Validitas & Kriteria \\
\hline 1 & Kesesuaian soal dengan indikator & 96 & Sangat valid \\
2 & Soal mencerminkan yang akan di uji & 96 & Sangat valid \\
3 & Kebenaran konsep dalam soal & 95,9 & Sangat valid \\
4 & Rumusan kalimat komunikatif & 92,1 & Sangat valid \\
5 & Kalimat menggunakan bahasa yang baik dan benar & 93,5 & Sangat valid \\
6 & Rumusan soal tidak menimbulkan penafsiran ganda/ salah pengertian & 91,3 & Sangat valid \\
\hline & Rata-rata & 94,1 & Sangat valid \\
\hline
\end{tabular}

Tabel 5. Pengelompokan Perolehan Nilai Post test Kelompok Eksperimen

\begin{tabular}{ccccccc}
\hline No & Rentang Skor & Frekuensi & Persentase (\%) & Kriteria & $\begin{array}{c}\text { Rata-rata Nilai } \\
\text { Post test Kelas }\end{array}$ & $\begin{array}{c}\text { Rata-rata Ketuntasan } \\
\text { Belajar Kelas }\end{array}$ \\
\hline 1 & $91-100$ & 3 & 9,4 & Sangat baik & & \\
2 & $81-90$ & 7 & 21,9 & Baik & 79,0 & 81,3 \\
3 & $75-80$ & 16 & 50 & Cukup & & \\
4 & $<75$ & 6 & 18,7 & Kurang & & \\
\hline
\end{tabular}

Tabel 6. Pengelompokan Perolehan Nilai Post test Kelompok Kontrol

\begin{tabular}{ccccccc}
\hline No & Rentang Skor & Frekuensi & Persentase & Kriteria & $\begin{array}{c}\text { Rata-rata Nilai } \\
\text { Post test Kelas }\end{array}$ & $\begin{array}{c}\text { Rata-rata Ketuntasan Belajar } \\
\text { Kelas }\end{array}$ \\
\hline 1 & $91-100$ & 0 & 0 & $\begin{array}{c}\text { Sangat } \\
\text { baik }\end{array}$ & \\
2 & $81-90$ & 6 & 18,8 & Baik & 74,9 \\
3 & $75-80$ & 17 & 53,1 & Cukup & \\
4 & $<75$ & 9 & 34,4 & Kurang & \\
\hline
\end{tabular}

Tabel 7. Hasil Analisis Independent Samples t-Test Terhadap Nilai Post test Peserta didik

\begin{tabular}{|c|c|c|c|c|c|c|}
\hline \multirow{2}{*}{ Variabel } & \multicolumn{2}{|c|}{ Rata-rata nilai kelompok } & \multirow{2}{*}{$\begin{array}{c}\text { Levene's Test for Equality of Variances } \\
\text { (uji Homogenitas) }\end{array}$} & \multirow{2}{*}{$\begin{array}{c}\mathbf{t} \\
\text { hitung }\end{array}$} & \multirow{2}{*}{$\begin{array}{c}\mathrm{t} \\
\text { tabel }\end{array}$} & \multirow{2}{*}{$\begin{array}{c}\mathrm{P} \\
\text { (Signifikansi 2-tailed }\end{array}$} \\
\hline & Eksperimen & Kontrol & & & & \\
\hline Nilai post test & 79,0 & 74,9 & 0,741 & 2,089 & 1,999 & 0,041 \\
\hline
\end{tabular}

\section{PEMBAHASAN}

Hasil penilaian validator ahli isi dan materi pembelajaran terhadap modul menyatakan bahwa modul sangat layak digunakan dalam pembelajaran. Kelayakan ini ditinjau dari kelayakan isi, kebahasaan, sajian, dan kegrafisan yang memperoleh nilai rata-rata $91,8 \%$. Hal ini didukung oleh komentar validator secara umum menyatakan isi dan tampilan modul menarik dan layak digunakan dalam pembelajaran. 
Penilaian peserta didik terhadap modul secara keseluruhan dalam uji coba perorangan adalah sangat baik dengan nilai rata-rata $94,9 \%$. Pernyataan peserta didik secara umum menyatakan bahwa isi dan tampilan modul menarik, dapat memotivasi minat belajar dan membantu dalam memahami materi elektrokimia dan mengembangkan diri dalam berwirausaha dengan adanya muatan chemoentrepreneurship (kewirausahaan) yang terkait dengan materi tersebut.

Penilaian peserta didik terhadap modul secara keseluruhan dalam uji coba lapangan terbatas adalah sangat baik dengan nilai rata-rata $82,5 \%$. Penilaian tersebut meliputi aspek isi, bahasa, penyajian, dan kegrafisan. Hasil tersebut berbanding lurus dengan komentar peserta didik secara umum menilai modul pengembangan terkait isi dan tampilan yang menarik dan dapat membantu dalam memahami materi elektrokimia.

Hasil pengujian efektivitas modul menunjukkan bahwa modul efektif digunakan dalam pembelajaran. Hal ini dapat dilihat dari nilai rata-rata post test peserta didik kelompok eksperimen yaitu 79,0 yang lebih tinggi dari nilai rata-rata peserta didik kelompok kontrol yaitu 74,9 serta dilihat dari perbandingan persentase ketuntasan belajar kelas dimana kelompok eksperimen $81,3 \%$ peserta didik tuntas dan kelompok kontrol hanya $71,9 \%$. Pengujian lebih lanjut terhadap nilai post test kelompok eksperimen dan kontrol dengan uji-t menunjukkan bahwa ada perbedaan signifikan rata-rata nilai post test. Adanya aktivitas berpikir menggunakan pendekatan kontekstual dalam kegiatan pembelajaran, materi yang disampaikan secara runtut, bahasa yang komunikatif dalam modul terbukti dapat meningkatkan hasil belajar.

Chemoentrepreneurship sebagai salah satu inovasi pembelajaran kimia yang terkait dengan kewirausahaan dapat memberikan bekal kemampuan dan tambahan pengetahuan bagi peserta didik dalam mempelajari proses pengolahan suatu bahan kimia menjadi produk yang bernilai jual. Hal tersebut di buktikan dari hasil angket ahli isi, ahli pembelajaran, uji perorangan, uji lapangan terbatas menunjukkan hasil yang sangat baik dan positif.

\section{SIMPULAN}

Setelah melalui tahap pengembangan, validasi, pengujian, dan revisi dapat disimpulkan bahwa modul hasil pengembangan materi elektrokimia dengan pendekatan kontekstual chemoentrepteneurship untuk SMA kelas XII dikategorikan sangat layak ditinjau dari isi, bahasa, penyajian, dan kegrafisan untuk digunakan dalam kegiatan pembelajaran. modul hasil pengembangan terbukti efektif untuk digunakan dalam kegiatan pembelajaran.

Modul hasil pengembangan terbatas pada elektrokimia, maka perlu dikembangkan pada materi lain agar tersedia bahan ajar yang lengkap, penggunaan pendekatan kontekstual perlu dikembangkan lebih lanjut menggunakan pendekatan yang lain supaya peserta didik mempunyai pilihan dalam usaha memahami materi pembelajaran dan modul cetak diganti menjadi modul elektronik (e-modul) agar dapat menekan biaya cetak modul.

\section{DAFTAR RUJUKAN}

Ali, T. (2012). A Case Study of the Common Difficulties Experienced by High School Students in Chemistry Classroom in Gilgit-Baltistan (Pakistan). SAGE Open, 2(2), 1-13. https://doi.org/10.1177/2158244012447299

Andriani, F. (2011). Pengembangan Modul Pembelajaran Kimia untuk Kelas XI Semester III Program Kejuruan Teknik Mekanik Otomotif dengan Pendekatan Pembelajaran Berbasis Masalah (PBL). Tesis tidak diterbitkan. Universitas Negeri Malang, Malang.

Bennett, J., \& Holman, J. (2006). Context-Based Approaches to the Teaching of Chemistry: What are They and What Are Their Effects? Chemical Education: Towards Research-Based Practice, 165-184. https://doi.org/10.1007/0-306-47977-x_8

Chattopadhyay, A. (2005). Understanding of Genetic Information in Higher Secondary Students in Northeast India and the Implications for Genetics Education. Cell Biology Education, 4(1), 97-104. https://doi.org/10.1187/cbe.04-06-0042

Corebima, A. (2011). Berdayakan Keterampilan Berfikir Selama Pembelajaran Sains Demi Masa depan Kita. Makalah Seminar. Malang: Jurusan Biologi FMIPA UM. https://scholar.google.co.id/citations?user=EobB1ssAAAAJ\&hl=id

Cracolice, M. S., \& Ward, K. (1998). Integrating Service Learning into the College Chemistry Curriculum. The Chemical Educator, 3(3), 1-11. https://doi.org/10.1007/s00897980213a

Depdiknas. (2008). Penulisan Modul. Penulisan Modul, 98(1), 158-161. https://doi.org/http://dx.doi.org/10.1700/1053.11515

Fatmawati, L. (2013). Pengembangan Bahan Ajar Modul Elektrokimia untuk Siswa SMA Kelas XII IPA dengan Pendekatan Pembelajaran Inkuiri Terbimbing. Jurnal Pendidikan Sains, 1(2), 109-120.

Jacques-Fricke, B. T., Hubert, A., \& Miller, S. (2009). A Versatile Module to Improve Understanding of Scientific Literature Through Peer Instruction. Journal of College Science Teaching, 39(2), 24-32. Johnson, E. B. (2002). Kontekstual dan Penerapannya Dalam KBK. Universitas Negeri Malang. Malang: UM Press.

Josia Sanchaya Hendrawan, H. S. (2017). Pengaruh Sikap Mandiri, Motivasi, Pengetahuan Kewirausahaan terhadap Minat Berwirausaha (Studi Kasus pada Mahasiswa FEB UKSW Konsentrasi Kewirausahaan). AJIE - Asian Journal of Innovation and Entrepreneurship, 02(03), 291-314.

King, S. C., Meiselman, H. L., Hottenstein, A. W., Work, T. M., \& Cronk, V. (2007). The Effects of Contextual Variables on food acceptability: A Confirmatory Study. Food Quality and Preference, 18(1), 58-65.

https://doi.org/10.1016/j.foodqual.2005.07.014 
Kusuma, E. (2011). Pengembangan Bahan Ajar Kimia Berorientasi Chemo-Entrepreneurship untuk Meningkatkan Hasil Belajar dan Life Skill Mahasiwa. Jurnal Inovasi Pendidikan Kimia, 4(1), 544-551.

Lawhon, D. (1976). Instructional Development for Training Teachers of Exceptional Children: A Sourcebook. Journal of School Psychology, 14(1), 75. https://doi.org/10.1016/0022-4405(76)90066-2

Mursalin, E. (2015). Pengembangan Bahan Ajar Bervisi Sets (Science, Environment, Technology, and Society) dan Berbasis Kewirausahaan Kimia (Chemoentrepreneurship) Kompetensi Terkait Hidrokarbon dan Minyak Bumi. Pawiyatan, 22(2).

Nentwig, P. M., Demuth, R., Parchmann, I., Gräsel, C., \& Ralle, B. (2007). Chemie im Kontext: Situating Learning in Relevant Contexts While Systematically Developing Basic Chemical Concepts. Journal of Chemical Education, 84(9), 1439-1444. https://doi.org/10.1021/ed084p1439

Nurhadi \& Senduk, A. G. (2003). Kontekstual dan Penerapannya Dalam KBK. Malang: UM Press.

Özgelen, S. (2012). Students' Science Process Skills within a Cognitive Domain Framework. Eurasia Journal of Mathematics, Science and Technology Education, 8(4), 283-292. https://doi.org/10.12973/eurasia.2012.846a

Prastowo, A. (2014). Panduan Kreatif Membuat Bahan Ajar Inovatif. PLoS Medicine. https://doi.org/10.1016/j.burns.2014.02.013

Prayitno, M.A., Nanik, W., \& Sri, M. (2017). Penerapan Modul Kimia Berpendekatan Chemoentrepreneurship untuk Meningkatkan Kecakapan Hidup dan Motivasi Belajar. Journal of Innovative Science Education (JISE).

Sa'adah, N., \& Supartono. (2013). Penggunaan Pendekatan Chemoentrepreneurship pada Materi Larutan Penyangga untuk Meningkatkan Life Skill Siswa. Chemistry in Education, 2(2), 111-117.

Sumarti, S. S., Aris, S. R. S., \& Aini, R. N. (2018). Chemoentrepreneurship with Cooperative Integrated Process Inquiry Strategy to Increase Entrepreneurial Interest and Learning Motivation. Jurnal Pendidikan IPA Indonesia. https://doi.org/10.15294/jpii.v7i2.12206

Wikhdah, I. M. (2016). Pengembangan Modul Larutan Penyangga Berorientasi Chemoentrepreneurship (CEP) untuk Kelas XI SMA/MA. Jurnal Inovasi Pendidikan Kimia, 9(2).

Yunus, F. W., \& Ali, Z. M. (2012). Urban Students' Attitude towards Learning Chemistry. Procedia - Social and Behavioral Sciences, 68, 295-304. https://doi.org/10.1016/j.sbspro.2012.12.228 